\title{
Patient Experience and Perspective towards Optometry Students during Eye Examination and Consultation in UiTM Vision Care Clinic
}

\author{
Elly Liyana Zainodin, Nur Afiqah Mohd Nor Azmi \\ Centre of Optometry, Faculty of Health Sciences, \\ Universiti Teknologi MARA Cawangan Selangor, Kampus Puncak Alam, 42300 Selangor, Malaysia \\ ellyzainodin@gmail.com, nurafiqahazmi961@gmail.com \\ Tel: 0149678687
}

\begin{abstract}
Clinical training for optometry students is a gateway for exposure in eye care management. Understanding patient experience and satisfaction of being examined by students is essential to improve clinical competency and education. A survey was done to determine patient experience and perspective among 228 adults who had eye examinations at the UiTM Vision Care clinic. Overall, the majority of the patients rated the care as good (96\%) and believed it is vital for students to examine patients $(93 \%)$. Patients of the fourth-year students were reportedly more happy for future student involvement. Concerns on lengthy examination recommend necessary measures.
\end{abstract}

Keywords: patient experience; optometry; students; clinical education

eISSN: 2398-4287 @ 2019. The Authors. Published for AMER ABRA cE-Bs by e-International Publishing House, Ltd., UK. This is an open access article under the CC BYNC-ND license (http://creativecommons.org/licenses/by-nc-nd/4.0/). Peer-review under responsibility of AMER (Association of Malaysian Environment-Behaviour Researchers), ABRA (Association of Behavioural Researchers on Asians) and cE-Bs (Centre for Environment-Behaviour Studies), Faculty of Architecture, Planning \& Surveying, Universiti Teknologi MARA, Malaysia.

DOI: https://doi.org/10.21834/e-bpj.v4i12.1932

\subsection{Introduction}

All universities offering optometry courses in Malaysia provide clinical training for their third and fourth-year students. Optometry students obtain clinical experiences and exposure to a variety of optometric cases through their clinical training sessions. Student involvement in clinical training is essential to enhance their skills, to build their confidence in communication, and to increase their experience in managing eye problems. With proper and sufficient clinical training, students are expected to have more confidence and competent by the time of their graduation. However, the key to those outcomes is the students' ability to interact and communicate with the patients effectively. Excellent communication is critical in building the optometrist-patient relationship and is vital in ensuring a successful provision of eye care services (Brandenburg \& Pesudovs, 2014). DiMatteo \& Hays (1980) stated that effective communication is a critical component in medical care that demands a good explanation of the diagnosis and treatment to enhance compliance and acceptance of the patients. Patients' perceptions toward their doctors' competence, knowledge, and attitude can influence the outcome of treatment as their judgments influence their behaviour and commitment. In clinical training of optometry students, patient's involvement and cooperation in the examination could be depending on their satisfaction and experience of being examined by the examiner. Therefore, understanding the patient satisfaction and experience from being examined by clinical optometry students is crucial as it helps the students to improve their approach and interaction with patients.

\subsection{Literature review}

Several studies have been done to investigate patients' experiences and attitudes during consultations (Howe \& Anderson, 2003; Mol, Peelen, \& Kuyvenhoven, 2011; Sayed-Hassan, Bashour, \& Koudsi, 2012). Those studies focusing on medical students reported more

eISSN: 2398-4287 (C) 2019. The Authors. Published for AMER ABRA cE-Bs by e-International Publishing House, Ltd., UK. This is an open access article under the CC BYNC-ND license (http://creativecommons.org/licenses/by-nc-nd/4.0/). Peer-review under responsibility of AMER (Association of Malaysian Environment-Behaviour Researchers), ABRA (Association of Behavioural Researchers on Asians) and cE-Bs (Centre for Environment-Behaviour Studies), Faculty of Architecture, Planning \& Surveying, Universiti Teknologi MARA, Malaysia. DOI: https://doi.org/10.21834/e-bpj.v4i12.1932 
positive feedback than negative feedback from the patient with regards to consultations. Choudhury et al. (2006) found that elderly patients seemed to be more favourable towards medical student involvement in their care. Those who have prior experience having medical students during consultations also found to be the ones more likely to give positive feedbacks compared to the first-timer patients. Benson, Quince, Hibble, Fanshawe, \& Emery (2005) reported that patients generally support the teaching of medical students to practice as they felt good about contributing to student learning.

A search of the literature revealed only one study which evaluates the patient's experience and perception of optometry students' examination. The study by Bentley, Trevaskis, Woods, Guest, \& Watt, (2018) investigates patient satisfaction of consultation in teaching and non-teaching clinics. They reported that the majority of patients in the clinical teaching clinic were comfortable with the optometry students involved in their clinical care. Prolong examination was the main reason for those who were unwilling to have students participating in their consultation. Understanding the patients' experience and perception is essential to improve student competency. However, no local survey has investigated the patient experience and perception from attending student optometry consultation at the internal university clinic. This study, therefore, sets out to determine the patients attending UiTM Vision Care Clinic experience and perception towards optometry students' examination and consultations. Additionally, this study evaluates whether there is a difference in the patient experience and perception with different years of clinical training.

\subsection{Methodology}

\subsection{Materials of the study}

The patient experience and perception from participating in the optometry student examination and consultations in UiTM Vision Care Clinic were evaluated using a questionnaire in cross-sectional study design. The questionnaire was adopted from the previous study by Bentley et al., (2018) that surveyed the impact of supervised student optometry consultations on the patient experience. The original set of the questionnaire was in English. The questionnaire was translated into the Malay language to suit the targeted participants. Several original questions were removed from the questionnaire when identified as unrelated to the objective of the current study. A draft version of the survey was pilot-tested on five individuals to ensure clarity of the questions and was accordingly revised. The final questionnaire comprised 30 questions divided into three sections; (A) the demographics, (B) care and treatment received in the clinic, (C) patient's overall experience. Most questions (28) were closed-ended questions in a multiple-choice format, while two were open-ended questions. All open-ended responses coded by two researchers independently and a discrepancy in any of the coded answers were discussed together until a mutual agreement of the final theme was achieved.

\subsection{Procedures}

The questionnaires were distributed to a total of 228 patients attending the UiTM Vision Care Clinic from February to April 2019. The questionnaires were distributed equally to patients of the third year (114) and fourth year (114) students to allow comparison. The questionnaire was self-administered, and it took about 10 minutes to complete. Subjects excluded from the study were pediatric patients or patients identified as optometry students or staff. Ethics approval was obtained from the UiTM Research Ethics Committee.

\subsection{Data analysis}

Statistical analysis using the SPSS statistical software program (SPSS 21.0) was performed. Descriptive statistics were computed. The chi-square test was done at $\alpha=0.05$ significance level to assess the differences in patient experiences between groups.

\subsection{Findings}

\subsection{Patient characteristics}

Of the 228 patients, the majority were Malay ( $n=223)$ females $(n=186)$, aged between 18 to 25 years ( $n=198)$, and has a university degree $(n=150)$.

\subsection{Overall patient experience in UiTM Vision Care Clinic}

Of the 228 patients seen in UiTM Vision Care Clinic, 95\% perceived the receptionist staff as helpful, and $97 \%$ reported that they were treated with respect and dignity. The majority of the patients $(85 \%)$ knew that optometry students received their training at the UiTM Vision Care Clinic, felt that they contributed to student learning (85\%), and believed that it is essential for students to work with patients $(93 \%)$. Most of the patients reported the optometrist, and students worked very well together (76\%), and they did not felt annoyed at repeating information to the student or the clinical supervisor $(71 \%)$. When the patients were asked whether their eye was in better care with the presence of the student, $76 \%$ agreed that their care was better with student involvement, with $96 \%$ rated the overall care they received as very good or good (Table 1).

Patients were asked via open-ended questions to comment about their overall eye care experience in UiTM Vision Care Clinic. Fiftyone provided comments, with the majority of patients, gave positive feedback about their experiences in the clinic (47 comments), whereas only four patients expressed their experience negatively. Both positive and negative comments were grouped according to similar themes and summarized in Table 2. Themes surfaced as positive were good services at the clinic (15 comments), good explanation on eye care by the students ( 7 comments), and comprehensive eye examination ( 1 comment). There were twenty-two 
positive comments were non-specific to any themes. Long examination time (3 comments) and incompetent student (1 comment), on the other hand, denotes negative feedbacks from the patients.

Table 1. Comments about overall eye care experience from patients in UiTM Vision Care Clinic

\begin{tabular}{|c|c|c|}
\hline 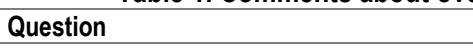 & Response & Frequency (\%) \\
\hline \multirow[t]{3}{*}{ Receptionist helpful } & Yes, definitely & $217(95)$ \\
\hline & Yes, to some extent & $11(5)$ \\
\hline & No & 0 \\
\hline \multirow[t]{4}{*}{ Clinical supervisor introduction } & Do not know/cannot remember & $8(3)$ \\
\hline & Some of the staff introduced themselves & $27(12)$ \\
\hline & Very few or none of the staff introduced themselves & \\
\hline & Yes, all of the staff introduced themselves & $187(82)$ \\
\hline \multirow{3}{*}{$\begin{array}{l}\text { Knowing students trained at UiTM Vision } \\
\text { Care Clinic }\end{array}$} & Yes & 194(85) \\
\hline & No & $28(12)$ \\
\hline & Not sure & $6(<1)$ \\
\hline \multirow[t]{4}{*}{ Annoyed at repeating information } & No & 162(71) \\
\hline & This did not happen & $46(20)$ \\
\hline & Yes, a little & $14(6)$ \\
\hline & Yes, definitely & $6(3)$ \\
\hline \multirow{3}{*}{$\begin{array}{l}\text { Believe it is important for students to work } \\
\text { with patients }\end{array}$} & Yes, completely & $211(93)$ \\
\hline & Yes, to some extent & $17(7)$ \\
\hline & No & 0 \\
\hline \multirow[t]{3}{*}{ Feel contributed to student learning } & Yes, completely & 194(85) \\
\hline & Yes, to some extent & $34(15)$ \\
\hline & No & 0 \\
\hline \multirow[t]{3}{*}{ Treated with respect and dignity } & Yes, completely & 222(97) \\
\hline & Yes, to some extent & $6(3)$ \\
\hline & No & 0 \\
\hline \multirow{5}{*}{$\begin{array}{l}\text { How well the optometrist and student } \\
\text { worked together }\end{array}$} & Very poor & 0 \\
\hline & Poor & 0 \\
\hline & & $8(4)$ \\
\hline & Good & $47(20)$ \\
\hline & Very good & $173(76)$ \\
\hline \multirow{3}{*}{$\begin{array}{l}\text { Optometrist and student talked as if you } \\
\text { were not there }\end{array}$} & Yes, often & $7(3)$ \\
\hline & Yes, sometimes & 20(9) \\
\hline & No & $201(88)$ \\
\hline \multirow{3}{*}{$\begin{array}{l}\text { Better care because of student } \\
\text { Involved }\end{array}$} & Yes, completely & 173(76) \\
\hline & Yes, to some extent & $52(23)$ \\
\hline & No & $3(1)$ \\
\hline \multirow[t]{5}{*}{ Overall rating of care } & Very poor & 0 \\
\hline & Poor & 0 \\
\hline & & $8(4)$ \\
\hline & Good & $38(16)$ \\
\hline & Very good & $182(80)$ \\
\hline
\end{tabular}

Table 2. Comments about overall eye care experience from patients in UiTM Vision Care Clinic

\begin{tabular}{|c|c|c|c|c|c|}
\hline Positive Experiences & & & Negative exper & & \\
\hline Theme & $\begin{array}{l}\text { No. of } \\
\text { responses }\end{array}$ & Examples of response & Theme & $\begin{array}{l}\text { No. of } \\
\text { responses }\end{array}$ & Examples of responses \\
\hline Good services & 15 & $\begin{array}{l}\text { "Excellent services". } \\
\text { "Very professional in doing their job". } \\
\text { "Service provided is good". }\end{array}$ & Long chair time & 3 & $\begin{array}{l}\text { "Took a long time to finish the } \\
\text { examination". }\end{array}$ \\
\hline $\begin{array}{l}\text { Good explanation on } \\
\text { eye care/ informative }\end{array}$ & 7 & $\begin{array}{l}\text { "Clear in explaining the treatments } \\
\text { given". } \\
\text { "I received much input". } \\
\text { "The student was so friendly and } \\
\text { knowledgeable as well as willing to } \\
\text { learn from the supervisor". "I was so } \\
\text { happy with the result, and I felt relieved } \\
\text { to know my eyes are fine". } \\
\text { "I gain sufficient information about my } \\
\text { eyes and comfortable with the } \\
\text { treatment given". }\end{array}$ & $\begin{array}{l}\text { Student } \\
\text { competency }\end{array}$ & 1 & $\begin{array}{l}\text { "The students need to have } \\
\text { good clinical skills and } \\
\text { improve their skills". }\end{array}$ \\
\hline Positive Experiences & & & Negative exper & & \\
\hline Theme & $\begin{array}{l}\text { No. of } \\
\text { responses }\end{array}$ & Examples of response & Theme & $\begin{array}{l}\text { No. of } \\
\text { responses }\end{array}$ & Examples of responses \\
\hline $\begin{array}{l}\text { The eye examination is } \\
\text { comprehensive }\end{array}$ & 1 & "The examination was very thorough". & & & \\
\hline
\end{tabular}




\begin{tabular}{ll}
\hline Others & "The environment at UiTM Vision Care \\
& Clinic is good". \\
& "No, I am very satisfied with how I was \\
& treated as well as cared for, and the \\
& amiable environment made me feel at \\
& ease". \\
& "I will come again because I am not \\
& afraid to share my eye problem". \\
\end{tabular}

4.3 Comparison of the patient experience examined by third-year optometry students versus fourth-year optometry students Table 3 compares the patient experience between those who were examined by the third-year optometry students and those examined by the fourth-year students. There were no significant differences between the two groups in the perception of student professionalism, confidence, and trust toward the student, and both groups feel comfortable with the student ( $p>0.05)$. Both groups of patients also had their permission sought for student involvement in their eye examination $(p=0.08)$. However, the overall performance of the fourth-year students was rated better than the third-year students $(p=0.01)$. More patients examined by the fourth-year students reported that they are happy to have student involvement in their eye care again $(p=0.03)$, they were willing to return to the clinic in the future $(p=0.02)$, and that the student communicates with them appropriately $(p=0.001)$. Between the two groups, third-year students have seen more patients $(82 \%)$ who had their first experience of an eye examination with a student $(p=0.03)$. A significant difference in the time spent at the clinic between the two groups of patients was reported $(p<0.001)$, where more third-year students $(20 \%)$ examined their patients longer than 2 hours in the clinic than the fourth-year students $(8 \%)$.

Patients of both groups were further asked to explain the reason for their willingness or reluctance to have a student involved in their eye care again (Table 4). Several themes emerged from the responses among those who were willing. The majority of patients in both groups indicate the need for a student to have opportunities to learn and have real patient experience as their main reason. Two patients were stating they were not willing to have student involvement again because the examination takes a long time were patients of the third-year. Another two patients were uncertain if they would want a student to be involved in their examination again because the examination took a long time to complete and that they doubted the accuracy of the examination performed by the student.

Table 3. Comparison of patient experience examined by third-year optometry students versus fourth-year optometry students

\begin{tabular}{|c|c|c|c|c|}
\hline Question & Response & The third year, $\mathrm{n}(\%)$ & Forth year, $\mathrm{n}(\%)$ & $p$-value \\
\hline \multirow[t]{3}{*}{ First experience with student } & Yes & $94(82)$ & $81(71)$ & 0.03 \\
\hline & No & $18(16)$ & $33(29)$ & \\
\hline & Not sure & $2(2)$ & 0 & \\
\hline \multirow{3}{*}{$\begin{array}{l}\text { Permission sought for } \\
\text { student involvement }\end{array}$} & Yes & 108(95) & 103(90) & 0.08 \\
\hline & No & 0 & $5(4)$ & \\
\hline & Not sure & $6(5)$ & $6(6)$ & \\
\hline \multirow{4}{*}{ Length of time at the clinic } & Less than 30 minutes & 0 & $4(4)$ & 0.000 \\
\hline & 30 minutes to 1 hour & $13(11)$ & $32(28)$ & \\
\hline & More than 1 hour but less than 2 & $78(68)$ & $69(60)$ & \\
\hline & $\begin{array}{l}\text { hours } \\
\text { More than } 2 \text { hours }\end{array}$ & $23(20)$ & $9(8)$ & \\
\hline \multirow{5}{*}{$\begin{array}{l}\text { Thoughts on the amount of } \\
\text { time spent at the clinic }\end{array}$} & About right & $85(75)$ & $90(79)$ & 0.34 \\
\hline & Slightly too short & $1(1)$ & $2(2)$ & \\
\hline & Slightly too long & $22(19)$ & $18(15)$ & \\
\hline & Much too short & $1(1)$ & $3(3)$ & \\
\hline & Much too long & $5(4)$ & 1(1) & \\
\hline \multirow[t]{3}{*}{ Comfortable with student } & Yes, completely & 107(94) & 110(96) & 0.35 \\
\hline & Yes, to some extent & $7(6)$ & $4(4)$ & \\
\hline & No & 0 & 0 & \\
\hline \multirow{3}{*}{$\begin{array}{l}\text { Treated with respect and } \\
\text { dignity by student }\end{array}$} & Yes, completely & 104(91) & $114(100)$ & 0.001 \\
\hline & Yes, to some extent & $10(9)$ & 0 & \\
\hline & No & 0 & 0 & \\
\hline \multirow[t]{3}{*}{ Students were professional } & Yes, completely & 109(96) & 113(99) & 0.10 \\
\hline & Yes, to some extent & $5(4)$ & $1(1)$ & \\
\hline & No & 0 & 0 & \\
\hline \multirow{3}{*}{$\begin{array}{l}\text { Student communicated } \\
\text { appropriately }\end{array}$} & Yes, completely & 104(91) & 114(100) & 0.001 \\
\hline & Yes, to some extent & $10(9)$ & 0 & \\
\hline & No & 0 & 0 & \\
\hline Question & Response & The third year, $\mathrm{n}(\%)$ & Forth year, $\mathrm{n}(\%)$ & p-value \\
\hline \multirow{3}{*}{$\begin{array}{l}\text { Confidence and trust in the } \\
\text { student }\end{array}$} & Yes, completely & $99(87)$ & $107(94)$ & 0.07 \\
\hline & Yes, to some extent & $15(13)$ & $7(6)$ & \\
\hline & No & 0 & 0 & \\
\hline \multirow[t]{5}{*}{ Overall rating of student } & Very poor & 0 & 0 & 0.01 \\
\hline & Poor & 0 & 0 & \\
\hline & Fair & 1(1) & 0 & \\
\hline & Good & $37(32)$ & 19(17) & \\
\hline & Very good & $76(67)$ & $95(83)$ & \\
\hline \multirow{3}{*}{$\begin{array}{l}\text { Happy to have a student } \\
\text { involved in care again }\end{array}$} & Yes & $98(63)$ & 109(96) & 0.03 \\
\hline & Maybe & $13(11)$ & $5(4)$ & \\
\hline & No & $3(26)$ & 0 & \\
\hline
\end{tabular}




\begin{tabular}{|c|c|c|c|c|c|}
\hline \multicolumn{2}{|c|}{$\begin{array}{l}\text { Would return to the clinic in } \\
\text { future }\end{array}$} & $\begin{array}{l}\text { Yes } \\
\text { No } \\
\text { Maybe }\end{array}$ & $\begin{array}{l}89(78) \\
0 \\
25(22) \\
\end{array}$ & & $\begin{array}{l}102(89) \\
0 \\
12(11)\end{array}$ \\
\hline & & \multicolumn{2}{|c|}{ Third-year students } & \multicolumn{2}{|c|}{ Fourth-year students } \\
\hline Willingness & Theme & No. of responses & Examples of responses & No. of responses & Examples of responses \\
\hline \multirow[t]{7}{*}{ Yes } & $\begin{array}{l}\text { Opportunity to } \\
\text { learn for the } \\
\text { students }\end{array}$ & 10 & $\begin{array}{l}\text { "They can experience } \\
\text { new cases for learning". } \\
\text { "They can have real } \\
\text { experience to enhance } \\
\text { their skills". } \\
\text { "They can learn from their } \\
\text { mistakes". }\end{array}$ & 14 & $\begin{array}{l}\text { "Give the opportunity to examine eye health". } \\
\text { "We learn new things together". } \\
\text { "I am happy to be able to help other students to } \\
\text { study and better their knowledge and practice in the } \\
\text { study". } \\
\text { "Personal experience to students". }\end{array}$ \\
\hline & $\begin{array}{l}\text { Student's } \\
\text { communication }\end{array}$ & 4 & $\begin{array}{l}\text { "A fun way of examination } \\
\text { and clear in explaining". }\end{array}$ & 9 & $\begin{array}{l}\text { "Easy to communicate". } \\
\text { "More comfortable to communicate with students in } \\
\text { the eye examination". }\end{array}$ \\
\hline & $\begin{array}{l}\text { Comfortable with } \\
\text { students }\end{array}$ & 4 & "I feel more comfortable". & 6 & $\begin{array}{l}\text { "Not afraid to share the problem of my eyes". } \\
\text { "I am comfortable". } \\
\text { "Not shy to ask regarding eye problems and can } \\
\text { know the purpose of each procedure in the eye } \\
\text { examination". }\end{array}$ \\
\hline & $\begin{array}{l}\text { Completeness of } \\
\text { examination }\end{array}$ & 0 & & 2 & "The examination was thorough". \\
\hline & $\begin{array}{l}\text { Student's } \\
\text { competency }\end{array}$ & 1 & $\begin{array}{l}\text { "Good in handling } \\
\text { patients". }\end{array}$ & 1 & "The student was very good". \\
\hline & $\begin{array}{l}\text { Student's } \\
\text { positive attitude }\end{array}$ & 3 & $\begin{array}{l}\text { "The student examines } \\
\text { with cautious in each } \\
\text { procedure". } \\
\text { "Because I feel } \\
\text { comfortable, and the way } \\
\text { she treated me, I feel like } \\
\text { she is professional." } \\
\text { "Polite". }\end{array}$ & 5 & $\begin{array}{l}\text { "Professionalism". } \\
\text { "The student was nice and polite". }\end{array}$ \\
\hline & Others & 2 & $\begin{array}{l}\text { "Trust in their examination } \\
\text { because there is a } \\
\text { supervisor to guide them". } \\
\text { "Good because the } \\
\text { supervisor checked all the } \\
\text { procedure". }\end{array}$ & 2 & $\begin{array}{l}\text { "They were more excited to share information about } \\
\text { the eyes and how to care the eyes". } \\
\text { "I have faith/trust in them, and I feel happy that I can } \\
\text { help them even though not much". }\end{array}$ \\
\hline No & & 2 & $\begin{array}{l}\text { "It is taking a long time, } \\
\text { and every test needs to } \\
\text { double-check by the } \\
\text { supervisor, so it takes a } \\
\text { long time". } \\
\text { "Take a too long time". }\end{array}$ & & \\
\hline Maybe & & 2 & $\begin{array}{l}\text { "Take time too long to } \\
\text { finish the examination". } \\
\text { "Not sure whether the } \\
\text { testing was done was } \\
\text { accurate or not". }\end{array}$ & & \\
\hline
\end{tabular}

\subsection{Discussion}

The results of this study showed a high degree of patient satisfaction on the overall care received at the UiTM Vision Care clinic. Positive patient experience rated by the majority of patients (96\%) attributed to excellent services in the clinic and good student explanations on eye care. These results are in agreement with that previously obtained by Bentley et al., (2018) among optometry students in the teaching clinic setting. Similar to finding on this study, a majority of their patients from the teaching clinic (98\%) also rated the care they received as good or excellent. Additionally, their patients similarly remarked happiness with the teaching clinic services for their positive experience in the clinic.

In other healthcare areas such as medical settings, findings were consistent that student participation does not affect patient satisfaction (Haffling \& Håkansson, 2008; Monnickendam, Vinker, Zalewski, Cohen, \& Kitai, 2001; Vaughn, Rickborn, \& Davis, 2015). However, the level of the student training year, age, and previous patient experience with a student were factors seem to influence the patient's attitude toward student involvement in medical student consultation (Choudhury et al., 2006). A comparison between optometry students of different years of clinical training in this study revealed a significant difference in student performance. More patients examined by the fourth-year students were willing to have a student involvement again and would return to the clinic compared to patients of the third-year. The main reason for the patients' willingness to have a student again was their desire to allow the students to learn to contribute to their education. The previous studies reported the same reason for patient acceptance with regards to optometry 
students (Bentley et al., 2018) and medical student involvement (Chipp, Stoneley, \& Cooper, 2004; Haffling \& Håkansson, 2008). Other reasons reported in this study were good student communication skills, and that the patient felt comfortable with the students.

The present finding also revealed that the fourth-year students significantly communicated better with their patients than third-year students and spent the lesser time to examine their patients. Due to the prolonged testing, a few of the third-year patients indicate they were reluctant to have a student again. The significant difference in the perspective and experience encountered by the patients was probably due to the difference in skills of the two groups of optometry students. The third-year students were in their first semester of clinical training during the data investigation thus may have less experience in patient handling skills compared with the fourth-year who were in their final semester of clinical training.

Good communication skills portrayed by a practitioner is critical in the optometrist-patient relationship, thus could result in a more positive outcome of examinations and consultations. Choudhury et al. (2006) presented in their study that younger patients are more likely to hold negative views when being examined by young students. Surprisingly, the young patients in this study indicate that they are more comfortable to share their eye problems with the optometry students in the clinic. A possible explanation for this might be because of the close approximation of age between the patients attending the UiTM Vision Care clinic, whose majority were young university students, and the optometry students who examined their eyes that made them feel more comfortable to ask questions and shared their eye problems.

\subsection{Limitations of Study}

Several limitations exist in this study. Since the majority of patients attending UiTM Vision Care Clinic were young students aged between 18 to 25 years, findings are less generalizable to older patients, or patients in employment. The patient experience and perspective in this study also did not represent a population with cultural diversity.

\subsection{Conclusion and Recommendations}

This study has shown that patients attending the UiTM Vision Care clinic generally had a good experience and a positive perspective on optometry students' examinations and consultations at the clinic. Nevertheless, patients who are seen by fourth-year students were more satisfied with the student's overall performance. The finding seems to suggest that the duration of clinical exposure reflects student competency. However, necessary steps should be taken by clinical trainers or educators on the issue of prolonged examination and consultation that arise. Future studies may investigate patient experience and perspective on optometry student examination and consultation of the older population in a multiracial setting.

\section{Acknowledgements}

We want to thank all patients attending the Primary Optometry Clinic at UiTM Vision Care, who had participated in this study as respondents. The Research Entity Initiative supported this study (Project code: 600-IRMI/REI 5/3 (016/2018).

\section{References}

Benson, J., Quince, T., Hibble, A., Fanshawe, T., \& Emery, J. (2005). Impact on patients of expanded, general practice based, student teaching: observational and qualitative study. BMJ, 331(7508), 89. https://doi.org/10.1136/bmj.38492.599606.8F

Bentley, S. A., Trevaskis, J. E., Woods, C. A., Guest, D., \& Watt, K. G. (2018). Impact of supervised student optometry consultations on the patient experience. Clinical and Experimental Optometry, 101(2), 288-296. https://doi.org/10.1111/cxo.12633

Brandenburg, R., \& Pesudovs, K. (2014). Teaching communication skills : an Australian optometry program's new course. Optometric Education, 40(1), 19-27. Retrieved from http://journal.opted.org/the-journal-of-optometric-education/optometric-education-vol-40-no-1-2014/teaching-communication-skills-an-australian-optometryprograms-new-course/

Chipp, E., Stoneley, S., \& Cooper, K. (2004). The Clinical TeacherClinical placements for medical students: factors affecting patients' involvement in medical education. Medical Teacher, 26(2), 114-119. https://doi.org/10.1080/01421590410001665636

Choudhury, T. R., Moosa, A. A., Cushing, A., \& Bestwick, J. (2006). Patients' attitudes towards the presence of medical students during consultations. Medical Teacher, 28(7), e198-e203. https://doi.org/10.1080/01421590600834336

DiMatteo, M. R., \& Hays, R. (1980). The significance of patients' perceptions of physician conduct: a study of patient satisfaction in a family practice center. Journal of Community Health, 6(1), 18-34. Retrieved from 10.1007/bf01324054

Haffling, A.-C., \& Håkansson, A. (2008). Patients consulting with students in general practice: Survey of patients' satisfaction and their role in teaching. Medical Teacher, 30(6), 622-629. https://doi.org/10.1080/01421590802043827

Howe, A., \& Anderson, J. (2003). Involving patients in medical education. BMJ, 327(7410), 326 LP - 328. https://doi.org/10.1136/bmj.327.7410.326

Mol, S. S. L., Peelen, J. H., \& Kuyvenhoven, M. M. (2011). Patients' views on student participation in general practice consultations: A comprehensive review. Medical Teacher, 33(7), e397-e400. https://doi.org/10.3109/0142159X.2011.581712 
Monnickendam, S. M., Vinker, S., Zalewski, S., Cohen, O., \& Kitai, E. (2001). Patients' attitudes towards the presence of medical students in family practice consultations. Israel Medical Association Journal, 3, 903-906. Retrieved from https://www.ima.org.il/MedicinelMAJ/viewarticle.aspx?year=2001\&month=12\&page=903

Sayed-Hassan, R. M., Bashour, H. N., \& Koudsi, A. Y. (2012). Patient attitudes towards medical students at Damascus University teaching hospitals. BMC Medical Education, 12(1), 13. https://doi.org/10.1186/1472-6920-12-13

Vaughn, J. L., Rickborn, L. R., \& Davis, J. A. (2015). Patients' Attitudes Toward Medical Student Participation Across Specialties: A Systematic Review. Teaching and Learning in Medicine, 27(3), 245-253. https://doi.org/10.1080/10401334.2015.1044750 